\title{
Praktik Model Bisnis Berkelanjutan pada Komunitas UMKM di Yogyakarta
}

\author{
Hendra Poerwanto G. ${ }^{1}$, Kristia ${ }^{2}$, Fransisca Desiana Pranatasari ${ }^{3}$ \\ ${ }^{1}$ Fakultas Ekonomi, Universitas Sanata Dharma \\ hendrapoerwanto@gmail.com, kristia9ie@gmail.com, fr.desiana@gmail.com
}

DOI: https://doi.org/10.24071/exero.v2i2.4050

\begin{abstract}
Abstrak
Setiap bisnis membutuhkan upaya untuk mulai memikirkan keberlanjutan bisnisnya. Sebagian besar bisnis memiliki tujuan utama untuk mengambil keuntungan, tetapi sekarang, mereka harus beralih ke pemikiran komprehensif tentang aspek lain di luar keuntungan, yaitu manusia dan planet. Profit, people, dan planet sering disebut triple bottom line. Dengan memperkuat aspek value proposition, value creation, dan value capture, UMKM di Indonesia akan bertahan dalam jangka panjang. Penelitian dilakukan pada komunitas UMKM di Yogyakarta yaitu Pasar Kamisan, Pasar Moncer dan Pasar Mustokoweni. Kami mewawancarai manajer utama dan anggota komunitas. Untuk mendukung data kualitatif, peneliti melakukan survei untuk melihat keselarasan misi komunitas dengan misi anggota komunitas. Hasilnya, para anggota merasa bahwa pengelola komunitas memiliki komitmen yang kuat untuk mendukung mereka dalam mencapai model bisnis yang berkelanjutan. Namun, dalam menerapkan model bisnis berkelanjutan ini tidaklah mudah. Berbagai tantangan dihadapi oleh pengelola komunitas maupun anggota.
\end{abstract}

Kata kunci: model bisnis berkelanjutan, triple bottom line, proposisi nilai, penciptaan nilai, penangkapan nilai

\begin{abstract}
Each business requires an effort to start thinking towards the sustainability of their business. Most businesses have a primary goal to take advantage, but now, they must turn to comprehensive thinking about other aspects beyond profit, namely people and planet. Profit, people and planet are often called tripple bottom line. Reinforcement the aspects of value proposition, value creation, and value capture, MSMEs in Indonesia will survive long-term. The study was conducted at the MSME community in Yogyakarta namely Pasar Kamisan, Pasar Moncer and Pasar Mustokoweni. We interview the main manager and community members. To support qualitative data, researchers conducted a survey to see the alignment of community missions with those of community members. As a result, members have felt that community managers have a strong commitment to support them in achieving a sustainable business model. However, in implementing this sustainable business model it is not easy. Various challenges faced by community managers as well as members.
\end{abstract}

Keywords: sustainable business model, tripple bottom line, value proposition, value creation, value capture

\section{Pendahuluan}

Model bisnis dipakai sebuah perusahaan ketika memulai usahanya. Dalam konsep manajemen, model bisnis dapat digunakan sebagai alat atau konsep yang membantu dalam menjelaskan bagaimana pengelolaan sebuah perusahaan dijalankan (Osterwalder dan Pigneur, 2010) melalui sembilan kategori yaitu key partners, key activities, key resourses, value proporsition, customer relationship, channels, customer segment, cost dan revenue streams. Alat ini dapat digunakan pula untuk menganalisis, mengukur kinerja perusahaan, mengelola, berkomunikasi bahkan juga 
untuk membuat inovasi (Osterwalder dan Pigneur, 2010). Dengan membuat model bisnis yang tepat, maka perusahaan dapat meraih profit sesuai dengan target mereka.

Perkembangan pemikiran konsep model bisnis menuntut sebuah usaha untuk mulai berpikir ke arah keberlanjutan usaha mereka. Keberlanjutan dalam hal ini bukan lagi semata-mata hanya memikirkan profit. Ketika sebuah bisnis hanya mementingkan profit saja, tanpa mereka sadari hal ini telah mengekploitasi sumber daya sekitar usaha mereka. Menurut WWF (2012), aktivitas konsumsi dan aktivitas bisnis yang dilakukan manusia telah tercatat menggunakan setidaknya 1.5 kali planet bumi kita. Eksploitasi inilah yang menjadi keprihatinan bersama untuk dicari solusinya karena praktik-praktik usaha lokal harus dikaitkan dengan global keberlanjutan bisnis (Høgevold, 2011). Bisnis yang berkelanjutan ini pada umumnya hanya diterapkan oleh perusahaan besar yang telah stabil secara finansial. Biasanya UMKM jarang melakukan hal ini karena terkendala permasalahan integrasi antar kepentingan stakeholder, keadaan finansial dan belum adanya kesadaran (Boons, 2013).

Tabel 1. Perkembangan Data Usaha Mikro, Kecil, Menengah (UMKM) dan Usaha Besar Tahun 2016- 2017

\begin{tabular}{|c|c|c|c|c|c|c|c|c|}
\hline \multirow[t]{2}{*}{ No } & \multirow[t]{2}{*}{ INDIKATOR } & \multirow[t]{2}{*}{ SATUAN } & \multicolumn{2}{|c|}{ TAHUN $2016^{\circ}$} & \multicolumn{2}{|c|}{ TAHUN $2017^{\circ-1}$} & \multicolumn{2}{|c|}{$\begin{array}{l}\text { PERKEMBANGAN } \\
\text { TAHUN 2016-2017 }\end{array}$} \\
\hline & & & JUMLAH & PANGSA (\%) & JUMLAH & PANGSA (\%) & JUMLAH & $\%$ \\
\hline (1) & (2) & (3) & (4) & (5) & (6) & (7) & (8) & (9) \\
\hline \multirow[t]{6}{*}{1} & UNIT USAHA (A+B) & (Unit) & 61.656 .547 & & 62.928 .077 & & 1.271 .529 & 2,06 \\
\hline & A. Usaha Mikro, Kecil dan Menengah (UMKM) & (Unit) & 61.651 .177 & 99,99 & 62.922.617 & 99,99 & 1.271 .440 & 2,06 \\
\hline & - Usaha Mikro (UMi) & (Unit) & 60.863 .578 & 98,71 & 62.106 .900 & 98,70 & 1.243 .322 & 2,04 \\
\hline & - Usaha Kecil (UK) & (Unit) & 731.047 & 1,19 & 757.090 & 1,20 & 26.043 & 3,56 \\
\hline & - Usaha Menengah (UM) & (Unit) & 56.551 & 0,09 & 58.627 & 0,09 & 2.075 & 3,67 \\
\hline & B. Usaha Besar (UB) & (Unit) & 5.370 & 0,01 & 5.460 & 0,01 & 90 & 1,67 \\
\hline
\end{tabular}

sumber: http://www.depkop.go.id/uploads/laporan/1549946778 UMKM\%2020162017\%20rev.pdf, diakses 25 November 2019

UMKM menjadi sasaran yang pas untuk melakukan penelitian ini karena jumlah UMKM di Indonesia yang cukup banyak. Berdasarkan informasi tabel 1 mengenai perkembangan data usaha mikro, kecil, menengah (UMKM) dan usaha besar diketahui bahwa tahun 2016- 2017, jumlah unit UMKM yaitu 2,06\% lebih besar daripada jumlah usaha besar yaitu hanya berjumlah 1,67\%. Oleh karena itu, perlu dicari solusi untuk membangun pemikiran model bisnis berkelanjutan pada UMKM untuk mengurangi eksploitasi bisnis yang berdampak pada ekonomi, sosial dan lingkungan.

Bisnis yang selama ini dibangun dengan memikirkan profit sebagai tujuan utamanya, pelan-pelan mulai beralih ke pemikiran yang komprehensif mengenai 
aspek lain diluar profit yaitu sosial (people) dan lingkungan (planet) yang lebih dikenal dengan istilah tripple bottom line (Battistella et al, 2018). Proses adaptasi penerapan tripple bottom line ini mempertimbangkan secara luas berbagai aspek kepentingan pemangku kepentingan termasuk lingkungan dan masyarakat (Evans et al, 2017).

Penerapan praktik model bisnis berkelanjutan merupakan salah satu bentuk komitmen pelaku bisnis yang diterapkan dengan cara memiliki tata kelola yang etis dan senantiasa berkontribusi terhadap perkembangan ekonomi dan tidak mengesampingkan kualitas kehidupan tenaga kerja, komunitas lokal dan masyarakat sekitar. Bisnis yang berkelanjutan ini pada umumnya hanya diterapkan oleh perusahaan besar yang telah stabil secara finansial, namun tidak menutup kemungkinan bahwa UMKM juga mampu mengaplikasikannya. Penguatan aspek value proposition, value creation, dan value capture maka UMKM di Indonesia mampu bertahan secara jangka panjang (Battistella et al, 2018).

Integrasi keberlanjutan yang menjadi inti bisnis dapat diciptakan melalui nilai sosial, lingkungan, dan ekonomi yang seimbang dengan pemetaan nilai dikembangkan untuk membantu perusahaan membuat proposisi nilai yang lebih cocok untuk keberlanjutan (Bocken, 2014). Penelitian kali ini dilakukan pada komunitas UMKM di Yogyakarta yaitu Pasar Kamisan, Pasar Moncer dan Pasar Mustokoweni dengan melakukan proses wawancara pada pengelola utama juga anggota komunitas. Untuk mendukung data kualitatif, peneliti melakukan survey untuk melihat keselarasan misi komunitas dengan yang dilakukan anggota komunitas. Peneliti ingin melihat bagaimana praktik penerapan model bisnis berkelanjutan pada komunitas dan anggota komunitas UMKM itu sendiri di Yogyakarta serta bagaimana tantangan yang dihadapi UMKM di Yogyakarta dalam mengadopsi model bisnis berkelanjutan. Manfaat dari penelitian ini dilakukan untuk meneliti mengenai langkah-langkah sederhana apa yang dapat dilakukan oleh UMKM dalam rangka mencapai suatu usaha yang berkelanjutan.

Hasilnya, anggota telah merasa bahwa pengelola komunitas memiliki komitmen kuat untuk mendukung mereka dalam mencapai model bisnis berkelanjutan. Hanya saja, dalam pelaksanaan model bisnis berkelanjutan ini memang tidak mudah. Berbagai tantangan dihadapi pengelola komunitas juga 
anggotanya. Elemen penting dari strategi yang sukses ini adalah untuk melihat keberlanjutan bukan sebagai tugas komunikasi, tetapi sebagai tantangan bagi semua bagian dari rantai nilai. (Høgevold, 2011).

\section{Kajian Literatur}

Untuk mengembangkan keunggulan kompetitif, sebuah bisnis perlu menemukan ceruk pasar yang cocok untuk usaha yang dikembangkannya. Bisnis harus berusaha untuk menjadi unik serta membangun komunitas dengan pelanggan sehingga keterhubungan dengan pelanggan pada tingkat emosional akan membantu usaha tersebut (Zimmerer, 2016). Ketika usaha berkonsentrasi pada inovasi dan menekankan kecepatan bekerja, maka secara jangka panjang, mereka akan mencapai keunggulan kompetitif mereka (Zimmerer, 2016).

Inovasi sebuah usaha hendaknya dilakukan secara terus menerus. Berbagai aspek dalam organisasi bisnis menuntut sebuah usaha perlu melakukan inovasi bahkan pada model bisnis mereka. Kesiapan perusahaan pada perubahan dimasa depan, akan menciptakan dampak signifikan pada tantangan yang muncul di berbagai aspek mulai dari ekonomi, sosial dan lingkungan (Bocken, 2014). Dalam pasar yang sangat kompetitif, banyak studi kasus yang menunjukkan bahwa berfokus pada dampak korporat dari lingkungan alam bisa sangat menguntungkan. Perusahaan perlu membawa proses bisnisnya menuju operasi bisnis yang berkelanjutan dengan dukungan dan komitmen oleh manajemen tingkat atas dan pemilik perusahaan secara jangka panjang (Høgevold, 2011).

\section{Pembentukan Nilai ke Arah Ekonomi Keberlanjutan}

Berbagai studi kini minta kembali pelaku bisnis untuk memikirkan kembali fondasi dan praktik bisnis yang mereka lakukan mengarah pada strategi bisnis yang keberlanjutan (sustainable value) atau tidak (Evans et al, 2017). Nilai keberlanjutan yang dimaksud menyiratkan adanya perubahan, inovasi, atau posisi penyesuaian entitas bisnis (Evans et al, 2017).

Pembangunan berkelanjutan adalah pembangunan yang memenuhi kebutuhan saat ini tanpa mengesampingkan kemampuan generasi mendatang untuk memenuhi kebutuhan mereka sendiri (Bocken et al, 2013). Untuk mengarahkan diri menjadi pembangunan yang berkelanjutan, maka setiap aktivitas baik konsumsi maupun 
bisnis terkait pemanfaatan sumber daya, hendaknya sudah mulai peduli terhadap masa depan generasi mendatang.

Menurut Bocken et al (2014), untuk mencapai ekonomi berkelanjutan, maka sebuah usaha perlu mengarahkan diri pada beberapa fitur pengembangan usaha sebagai berikut ini:

1. Sistem usaha dibuat dengan meminimalkan konsumsi dan mendorong efisiensi pemakaian energi, air, dan sumber daya lainnya.

2. Sebuah sistem yang dirancang untuk memaksimalkan masyarakat dan lingkungan manfaat, daripada memprioritaskan pertumbuhan ekonomi;

3. Mengubah sistem menjadi preferensi daur ulang sehingga tidak banyak yang dibiarkan sia-sia atau dibuang ke lingkungan. Barang digunakan kembali, diperbaiki, dan dibuat ulang.

4. Sistem yang dibangun berdasarkan kolaborasi dan berbagi, bukan kompetisi yang agresif

5. Sistem yang menekankan pengiriman fungsionalitas dan pengalaman. Pengalaman kerja yang memuaskan dan bermanfaat untuk semua yang meningkatkan kreativitas / keterampilan manusia

Untuk mencapai nilai berkelanjutan dapat dimulai dengan desain produk baru dan memastikan kriteria desain lingkungan terpenuhi. Hal ini melibatkan dan membutuhkan solusi yang lebih berkelanjutan mulai dari vendor, perantara dan memotivasi serta mengedukasi para pengecer dan konsumen semuanya terbukti merupakan bagian dari solusi untuk operasi bisnis yang berkelanjutan (Høgevold, 2011).

Perlunya keberlanjutan ekonomi, sosial dan lingkungan secara global menghadirkan tantangan bagi kesehatan, kesejahteraan dan lingkungan alam menghadirkan tantangan memberantas kemiskinan, sementara moderasi konsumsi berlebihan muncul dan berkembang negara, yang akan membutuhkan sistem sosialekonomi baru yang mempertimbangkan keterkaitan antara populasi, konsumsi dan lingkungan (Bocken et al, 2013). Aspek penting dalam model bisnis berkelanjutan ini mencakup sosial (people), lingkungan (planet) dan ekonomi (profit). Perspektif yang dipakai untuk memahami inovasi model bisnis yang mengarah pada organisasi yang lebih baik melalui kinerja ekonomi, lingkungan dan sosial (Evans et al, 2017). 
Tripple bottom line didefinisikan Evans et al (2017) dengan proses penciptaan keuntungan, manfaat sosial dan lingkungan dan keseimbangan diantaranya menuju keberlanjutan.

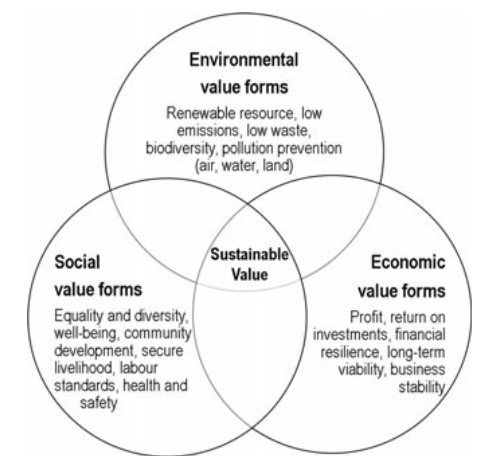

Gambar 1. Nilai Berkelanjutan

Sumber: Evans et al, 2017

Gambar 1 mengenai nilai berkelanjutan menjelaskan bahwa model bisnis berkelanjutan tidak harus dicapai melalui teknologi, produk atau inovasi layanan saja, tetapi juga melalui inovasi model bisnis itu sendiri. Dalam mencapai nilai berkelanjutan, lingkungan fokus pada sumber daya yang baru, sedikit sampah, pencegah polusi, dan perspektif daur ulang. Dalam mencapai nilai berkelanjutan, ekonomi fokus pada pencapaian profit, ROI, visibilitas, dan stabilitas bisnis. Dalam mencapai nilai berkelanjutan, sosial fokus pada keberagaman, kesejahteraan, pembangunan komunitas, kesehatan dan keamanan. Perubahan model bisnis yang dikonseptualisasikan ini erat kaitannya dengan pertukaran dan hubungan mereka dengan para pemangku kepentingan. Mereka saling mempengaruhi sehingga membentuk perilaku dan pandangan yang lebih luas secara jangka panjang. Perpindahan dari pola pikir transaksional menuju pengembangan berbasis kepercayaan, saling menguntungkan dan hubungan yang langgeng dengan pemangku kepentingan internal dan eksternal kunci ini juga salah satu ciri dari nilai berkelanjutan.

\section{Model Bisnis Berkelanjutan}

Perubahan pada model bisnis banyak diakui sebagai pendekatan yang mendasar untuk mewujudkan inovasi keberlanjutan. Di sisi lain, keberhasilan adopsi model bisnis yang berkelanjutan ini masih sedikit diterima oleh usaha yang skalanya kecil (Evans et al, 2017). Dengan memegang konsep nilai berkelanjutan, maka 
perusahaan perlu juga meninjau kembali model bisnisnya. Apakah model bisnis yang dikelola selama ini telah menunjukkan pengelolaan yang mengarah pada upaya berkelanjutan atau belum. Upaya peralihan model bisnis ini memiliki tantangan tersendiri bagi perusahaan. Perancangan ulang model bisnis dapat menjadi kunci untuk secara radikal meningkatkan kinerja berkelanjutan menciptakan nilai lingkungan dan sosial yang lebih besar sembari memberikan keberlanjutan ekonomi (Bocken et al, 2013). Perubahan tiga komponen utama dalam model bisnis yang menjadi tantangan bagi pelaku usaha adalah meliputi area proposisi nilai (value proposition), penciptaan nilai (value creation), dan penangkapan nilai (value capture) dalam satu konsep model bisnis berkelanjutan (Richardson, 2008). Model bisnis yang berkelanjutan dapat mendukung manajer untuk lebih memahami bagaimana hal itu dapat berkontribusi pada pembangunan berkelanjutan global melalui proposisi nilai perusahaan proposisi dan termasuk metode penciptaan nilai, pengiriman dan penangkapan (Morioka, Evans, dan Carvalho, 2016). Peluang inovasi dalam model bisnis berkelanjutan ini secara komprehensif dan integratif menjadi kerangka pengukuran kinerja yang diusulkan untuk mendukung identifikasi inovasi keberlanjutan.

Tantangan utama dalam penentuan proposisi nilai dari inovasi model bisnis yaitu menemukan tujuan dan penawaran bisnis yang dapat menjamin keunggulan kompetitif jangka panjang. Ide inovasi pada proposisi nilai dapat berupa penerapan ekonomi sirkuler, pembagian ekonomi, eko-efisiensi, bisnis inklusif, dasar piramida dan sistem layanan produk (Morioka, 2018). Terlepas dari banyaknya kemungkinan proposisi nilai, perusahaan yang menerapkan model bisnis berkelanjutan memiliki suatu kesamaan yaitu adanya upaya untuk mengintegrasikan aspek ekonomi, lingkungan, dan sosial, daripada hanya mengejar profit semata. Namun integrasi aspek ekonomi, sosial, lingkungan agak sulit untuk dikelola bersama karena sifatnya bertentangan dengan target profit pada penerapan ekonomi berkelanjutan (Bommel, 2018).

Tantangan kedua terkait dengan menciptakan nilai, yaitu mengembangkan model bisnis yang berkelanjutan melalui praktik-praktik khusus, kemampuan, dan sumber daya yang berorientasi pada keberlanjutan. Untuk menjawab tantangan ini, Bocken (2014) membuka jalan untuk konseptualisasi model bisnis yang 
berkelanjutan melalui identifikasi delapan pola dasar model bisnis yang berkelanjutan. Pola dasar tersebut menggambarkan solusi yang ditujukan untuk berkontribusi pada pengembangan model bisnis yang berkelanjutan. Pola dasar tersebut meliputi memaksimalkan efisiensi bahan dan energi, menciptakan nilai dari limbah, menggantikan dengan proses yang terbarukan dan alami, mengutamakan fungsionalitas daripada kepemilikan, mengadopsi peran penata layanan, mendorong kecukupan, mengarahkan kembali bisnis untuk masyarakat/lingkungan, mengembangkan solusi untuk peningkatan. Arketipe yang berbeda ini mewakili tantangan yang berbeda dalam hal penciptaan nilai, yang melibatkan praktik, kemampuan, dan sumber daya, seperti budaya organisasi, tata kelola perusahaan, operasi, inovasi dan penelitian dan pengembangan, operasi, rantai pasokan dan logistik, pemasaran dan penjualan (Bocken, 2014).

Tantangan ketiga adalah terkait dengan proses menangkap nilai dari model bisnis yang berkelanjutan. Faktor teknologi, organisasi, dan inovasi sosial seperti penggunaan sumber daya terbarukan, fleksibilitas waktu kerja dan perdagangan etis, membantu organisasi untuk menjembatani kesenjangan desain dengan implementasi dari inovasi model bisnis berkelanjutan, dengan cara menangkap nilai dari berbagai pelaku seperti pemegang saham investor, karyawan, pelanggan, pemasok/mitra, masyarakat, lingkungan, pemerintah dan juga menciptakan nilai berjenjang untuk mereka (e.g. Bocken, 2014; Morioka, 2018).

Perubahan pola pikir usaha menuju model bisnis berkelanjutan yang fokus pada area proposisi nilai (value proposition), penciptaan nilai (value creation), dan penangkapan nilai (value capture) ini juga mengedukasi pelanggan mereka untuk juga aktif berperilaku menuju nilai keberlanjutan (Richardson, 2008). Pelanggan menjadi lebih sadar lingkungan dan mempertimbangkan produk berdampak lingkungan dalam proses pembelian mereka sendiri sehingga dapat menjaga masa depan secara global baik dari sisi produsen maupun konsumen (Høgevold, 2011). 

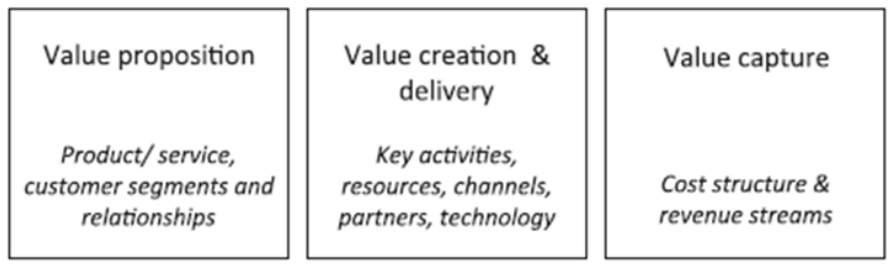

Gambar 2. Konseptual Model Bisnis Berkelanjutan

Sumber: Bocken, Rana, and Evans (2013)

Salah satu tantangan utama dalam merancang model bisnis berkelanjutan adalah pelaksanaan konseptual model bisnis seperti gambar 2 diatas. Perusahaan harus memposisikan produknya yang memiliki nilai proposisi berkelanjutan yang nampak pada aspek produk/jasa, segmentasi konsumen dan hubungannya dengan konsumen. Kemudian hal serupa juga memungkinkan perusahaan untuk menangkap nilai ekonomi untuk dirinya sendiri melalui memberikan manfaat sosial dan lingkungan melalui aktivitas kunci perusahaan, sumber daya yang dipakai, mitra kerja dan teknologinya. Penangkapan nilai dilakukan perusahaan melalui aktivitas struktur biaya dan pendapatannya. Menurut Bocken et al (2014) untuk meminimalisir resiko ketidakberhasilan penerapan model bisnis berkelanjutan, maka perlu adanya kategorisasi model bisnis berkelanjutan yang seluruh aktivitas usahanya mengarah kepada kategori ini, yaitu:

1. Maksimalkan efisiensi material dan energi

2. Ciptakan nilai dari 'buang' (zero waste)

3. Pengganti dengan energi terbarukan dan proses alami

4. Memberikan fungsionalitas, bukan kepemilikan

5. Mengadopsi peran penata layanan

6. Mendorong kecukupan

7. Mengarahkan kembali bisnis untuk masyarakat / lingkungan

8. Kembangkan solusi peningkatan

Model bisnis berkelanjutan hendaknya menyatukan berbagai aspek keberlanjutan. Didalam masing-masing kategorisasi diatas, memungkinkan adanya tingkat transformasi dan kegiatan organisasi terkait keberlajutan yang mendatangkan keuntungan ekonomi dan keuntungan kompetitif bagi perusahaan. Menurut Bocken et al (2014) menekankan pendekatan inovatif untuk kolaborasi. 
Banyak tantangan yang kemungkinan dihadapi oleh sebuah perusahaan untuk mampu secara sempurna menerapkan model bisnis berkelanjutan ini. Menurut Battistella et al (2018), setidaknya perusahaan perlu siap memikirkan beberapa tantangan berikut ini:

1. Dalam konteks proposisi nilai (value proposition) yaitu pelaksanaan tripple bottom line dan integrasi inovasi teknologi dengan inovasi model bisnis.

2. Dalam konteks penciptaan nilai (value creation) yaitu mengubah pola pikir/ mindset, pengelolaan sumber daya, dan metode serta alat.

3. Dalam konteks penangkapan nilai (value capture) yaitu hubungan dengan eksternal.

\section{Kerangka Pemikiran}

Beberapa hal yang perlu diperhatikan dalam pengembangan usaha mikro dan kecil adalah seputar mekanisme produksi dan pengolahan, pemasaran, sumber daya manusia, desain, teknologi dan menemukan keunggulan kompetitif. Inovasi model bisnis berkelanjutan inilah salah satu solusi mencapai keunggulan kompetitif. Oleh karena itu, kerangka pemikiran yang terbentuk adalah sebagai berikut ini:

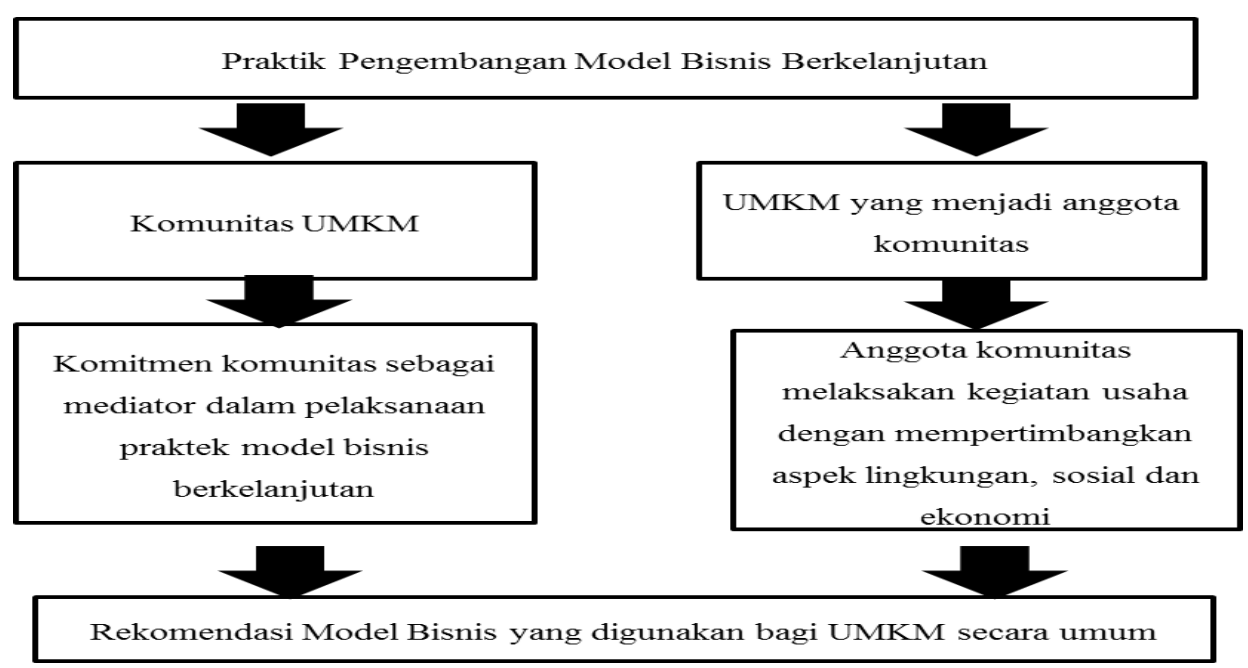

Gambar 3. Kerangka Penelitian 


\section{Metode Penelitian}

Penelitian ini adalah penelitan kualitatif deskriptif dengan wawancara mendalam sebagai metode pengumpulan data utamanya. Jenis penelitian deskriptif dipilih karena diharapkan dapat mendeskripsikan fenomena yang terkait dengan subjek (Cooper dan Schindler, 2014: 139). Metode penelitian kualitatif banyak digunakan pada pembuatan rencana bisnis dan manajemen pengambilan keputusan dalam hal pemaparan segmen pelanggan, pengembangan produk baru, pengujian konsep, dan pemahaman tentang pengambilan keputusan konsumen (Cooper dan Schindler, 2014:167). Narasumber dipilih berdasarkan kriteria yaitu pengelola komunitas UMKM yang berkomitmen menjalankan model bisnis berkelanjutan, usia komunitas UMKM ini setidaknya sudah 2 tahun, lokasi di Yogyakarta, anggota komunitas melakukan kegiatan yang linier dengan misi komunitasnya yaitu fokus pada keseimbangan antara keuntungan (profit), sosial (people), dan lingkungan (planet). Untuk mendukung data kualitatif, peneliti melakukan survey untuk melihat keselarasan misi komunitas dengan yang dilakukan anggota komunitas.

Di Yogyakarta, terdapat beberapa komunitas UMKM yang berkomitmen untuk mencapai sekonomi bekerlanjutan seperti Pasar Kamisan, Pasar Moncer, Pasar Milas, Pasar Sagan, Ndalem Natan, Pasar Sasen, Pasar Kebaikan, Pasar Lasem dan sebagainya. Atas pertimbangan konsistensi pelaksanaan kegiatannya, sumber data primer yang dilakukan dengan metode wawancara mendalam kepada jajaran manajemen komunitas UMKM Pasar Moncer, Pasar Mustokoweni, dan Pasar Kamisan yang dianggap telah menjalankan tata kelola berkelanjutan. Masing-masing komunitas diambil setidaknya sepuluh anggota UMKM secara convenience, untuk mengisi kuesioner penelitian. Untuk sumber data sekunder, penulis akan mengacu dari jurnal, artikel ilmiah, buku dan sumber lainnya yang mengulas tentang praktik model bisnis yang berkelanjutan. Objek penelitiannya yaitu pengalaman pengelola komunitas dalam menerapkan model bisnis berkelanjutan dengan fokus pada keseimbangan antara keuntungan (profit), sosial (people), dan lingkungan (planet) serta penguatan aspek value proposition, value creation, dan value capture agar UMKM di Indonesia mampu bertahan secara jangka panjang.

Untuk memastikan keabsahan data penelitian, peneliti menggunakan triangulasi sumber yang dilakukan dengan memberikan pertanyaan yang relatif sama 
kepada narasumber sehingga mendapatkan jawaban yang cenderung memiliki karakteristik sama untuk fenomena tertentu (Bungin, 2012:24). Data yang telah dikumpulkan, kemudian direduksi untuk disimpulkan menjadi suatu usulan desain pelaksanaan model bisnis berkelanjutan untuk komunitas UMKM di Yogyakarta. Dalam penelitian kualitatif, pikiran dan tubuh sang penelitilah yang berfungsi sebagai instrumen penelitian untuk menyerap, menyaring, dan menafsirkan dunia melalui pengamatan, partisipasi, dan wawancara (Tracy, 2013: 3).

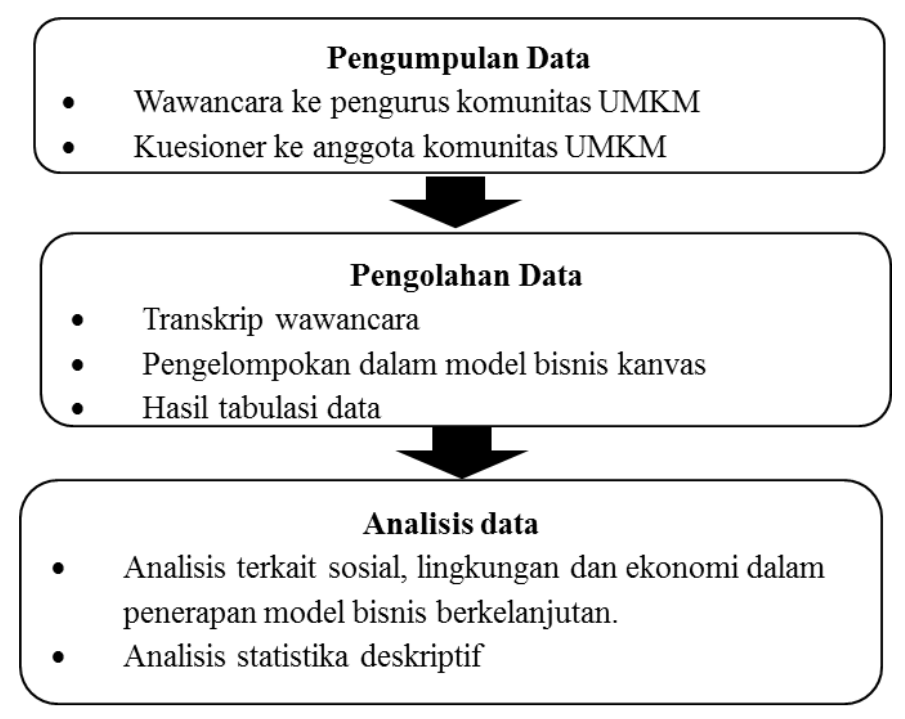

Gambar 4. Proses Analisis data

\section{Hasil dan Pembahasan}

Model bisnis berkelanjutan ini memiliki peran untuk mencapai masa depan berkelanjutan bagi UMKM yang merespon lingkungan ekonomi, sosial dan lingkungan. Inovasi model bisnis untuk keberlanjutan didefinisikan sebagai suatu penciptaan yang positif dan signifikan bagi lingkungan dan / atau masyarakat. Hal ini menuntut adanya perubahan dalam aktivitas dan segala proses organisasi dan jaringan nilainya. Kami berhasil melakukan proses wawancara mendalam ke beberapa narasumber sebagai berikut ini: 
Tabel 2. Narasumber Penelitian

\begin{tabular}{|c|c|c|c|c|c|}
\hline No & $\begin{array}{l}\text { Nama } \\
\text { (Kode) }\end{array}$ & $\begin{array}{c}\text { Peran dan } \\
\text { Tugas }\end{array}$ & $\begin{array}{c}\text { Komunitas } \\
\text { UMKM }\end{array}$ & $\begin{array}{l}\text { Tahun } \\
\text { berdiri }\end{array}$ & $\begin{array}{c}\text { Jumlah } \\
\text { Anggota }\end{array}$ \\
\hline 1. & $\begin{array}{l}\text { Agung Satria } \\
\text { Nugroho } \\
(\text { ASN) } \\
37 \text { tahun / } \\
\text { Laki-laki }\end{array}$ & $\begin{array}{ll}- & \text { Public } \\
& \text { relation } \\
- & \text { Koordinator } \\
\text { utama }\end{array}$ & $\begin{array}{c}\text { Pasar Kamisan } \\
\text { Jalan Kaliurang } \\
\text { KM 9,3 } \\
\text { Yogyakarta }\end{array}$ & 2015 & 15 buah \\
\hline 2. & $\begin{array}{l}\text { Anindita } \\
\text { Safitri (AS) } \\
43 \text { tahun / } \\
\text { perempuan }\end{array}$ & 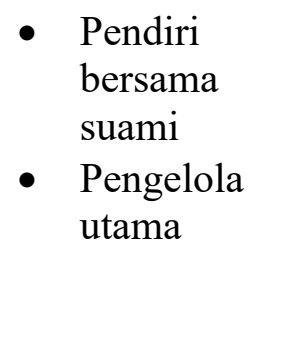 & $\begin{array}{l}\text { Pasar Moncer } \\
\text { Lokasi: } \\
\text { Kerjasama } \\
\text { dengan } \\
\text { Diperindag } \\
\text { Yogyakarta }\end{array}$ & 2018 & $\begin{array}{l}33 \text { buah } \\
\text { dengan } \\
\text { sistem } \\
\text { kurasi }\end{array}$ \\
\hline 3. & $\begin{array}{l}\text { Sarah Diorita } \\
\text { Prasetyo } \\
\text { (SDP) } \\
28 \text { tahun / } \\
\text { perempuan }\end{array}$ & 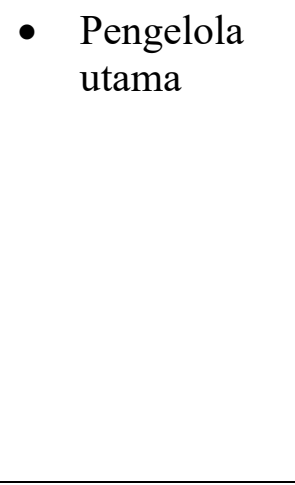 & $\begin{array}{c}\text { Pasar } \\
\text { Mustokoweni } \\
\text { Lokasi: Jl. A.M. } \\
\text { Sangaji, } \\
\text { Yogyakarta } \\
55233\end{array}$ & $\begin{array}{c}2016 \\
\text { lokasi } \\
\text { Sagan, } \\
\text { lalu } \\
\text { pindah } \\
\text { lokasi di } \\
\text { AM } \\
\text { Sangaji } \\
\text { tahun } \\
2018 \\
\end{array}$ & 24 buah \\
\hline
\end{tabular}

\section{Praktek Model Bisnis Berkelanjutan pada Komunitas UMKM Pasar Kamisan}

Pasar Kamisan adalah komunitas UMKM yang memiliki komitmen untuk menggerakkan semangat keberlanjutan bisnis yang tidak hanya mengejar profit saja namun juga keseimbangan rantai pasok antar pelaku bisnis. Semangat menjaga keseimbangan ini ditularkan juga kepada seluruh anggota komunitas UMKM ini. sejak tahun 2015, Pasar Kamisan telah konsisten menyelenggarakan kegiatannya bersama seluruh anggota di setiap hari kamis. Konsumen yang datang tidak hanya dari Yogyakarta saja, bahkan beberapa konsumen loyal dari luar kota pun kadang datang ke Yogyakarta di hari kamis untuk bisa meramaikan kegiatan Pasar Kamisan.

Anggota komunitas adalah UMKM yang produknya berasal dari rantai pasok level pertama. Pemangkasan rantai pasok ini penting untuk menjaga keseimbangan harga petani yang terkadang menjadi korban harga tengkulak. Bentuk komunitas bersifat non profit. Misinya hanya satu yaitu membawa anggota komunitas naik kelas dari segi bisnis dan menjaga keseimbangan usaha dengan sosial lingkungan. 
Dalam kaitannya dengan proposisi nilai, Pasar Kamisan memiliki kekhasan terkait dengan mayoritas produk yang dijual oleh anggota komunitasnya yaitu lebih mengarah kepada varian vegetarian termasuk di dalamnya susu dan telur serta produk lain yang memiliki sifat alami, bersih dan sehat. Syarat khusus untuk produk yang dijual antara lain tidak mengandung hewani, proses pengelolan produknya dengan cara sehat, produk lokal tangan pertama, tidak dengan minyak sawit. Kunjungan per minggunya kurang lebih 50 -100 pengunjung yang memiliki life style sehat, keluarga yang belanja, ibu rumah tangga, pekerja muda dan anak muda. Hubungan dengan konsumen mereka jaga tidak hanya dari komunitas saja namun masing-masing vendor menjaga loyalitas pelanggannya dengan membangun keercayaan akan produk yang aman untuk mereka.

Dalam kaitannya dengan penciptaan nilai kegiatan utama Pasar Kamisan adalah menjadi fasilitator kegiatan pasar dengan mengusung nilai keberlanjutan. Kegiatan lain yang menunjang adalah adanya edukasi kepada anggota komunitas terkait dengan pengembangan bisnis mereka baik dari segi strategi mencapai profit, strategi pengelolaan usaha yang peduli pada lingkungan, dan pengelolaan usaha yang berdampak pada sosial. Berdampak sosial dalam hal ini adalah pekerja yang berasal dari sekitar tempat tinggal mereka. Semua anggota komunitas menyadari bahwa mereka sama-sama menjalankan usaha untuk meningkatkan kepedulian pada lingkungan kesehatan dan keadaan sosial mereka. Koordinator komunitas pun kadang datang ke lokasi produksi anggota untuk memastikan bahwa anggota sungguh-sungguh melakukan misi yang diusung komunitas. Hal ini ditangkap juga sampai kepada mitra yang menjadi rekanan seperti pemilik tempat kegiatan Pasar Kamisan, desa pemasok, petani-petani, dan koperasi. Yang masih menjadi kelemahan adalah adopsi teknologi yang masih rendah untuk menopang fleksibilitas kegiatan usaha mereka. Karena UMKM masih terbatas modal, maka sebagian besar anggota masih menggunakan teknologi tepat guna yang sederhana sehingga harga produk kadang cenderung mahal dan sulit untuk produksi masal.

Dalam kaitannya dengan penangkapan nilai, misi Pasar Kamisan ini telah sampai kepada beberapa pihak eksternal yang sejalan dengan komunitas ini. Seperti halnya pemilik tempat yang juga peduli pada lingkungan dan kesehatan, memberikan persewaan gratis pada Pasar Kamisan untuk struktur biaya tempatnya. Hal ini 
sebagai bentuk kepedulian pemilik tempat pada lingkungan dan kesehatan. Pengelolaan komunitas ini tidak bersifat kelembagaan namun lebih kepada kekeluargaan, sehingga pendapatan komunitas yang berupa iuran ini hanya digunakan untuk anggota komunitas itu sendiri lagi.

Prinsipnya, komunitas Pasar Kamisan ini hadir untuk menjaga motivasi anggota UMKM menjalankan bisnis secara berkelanjutan karena memang tantangan yang besar untuk melanjutkan misi ekonomi berkelanjutan pada UMKM ini terletak pada komitmen UMKM itu sendiri mengenai bagaimana mempertahankan semangat mereka dalam mengembangkan produknya yang sejalan dengan aspek tripple bottom line. UMKM harus berani berubah demi kebaikan dan keinginan kosumen. Banyak diantaranya yang masih kaku dengan perubahan sehingga posisi mereka akan rentan untuk digantikan dengan lainnya. Di sisi lain, peluang kemajuan UMKM yang berkomitmen pada tripple bottom line ini masih sangat besar untuk dikembangkan karena adanya tren life style sehat diberbagai kalangan.

\section{Praktek Model Bisnis Berkelanjutan pada Komunitas UMKM Pasar Moncer}

Pasar Moncer adalah komunitas UMKM yang memiliki komitmen untuk menggerakkan semangat keberlanjutan bisnis yang tidak hanya mengejar profit saja namun juga keseimbangan rantai pasok antar pelaku bisnis. Moncer sendiri memiliki makna konsumen cerdas dan bersinar. Pasar Moncer ini aktif kembali sejak tahun 2018 yang pelaksanaan kegiatannya bekerjasama dengan Jogja for Nusantara dan Dinas Perindustrian dan Perdagangan Yogyakarta. Pasar Moncer ini aktif setiap bulannya dengan sistem kurasi pada UMKM pelaksana pamerannya.

Dalam kaitannya dengan proposisi nilai, syarat utama produk yang diperjual belikan ketika pameran bersama Pasar Moncer adalah produk tidak mengandung MSG, non pewarna buatan, non perisa buatan, gluten free, produk lokal, no reseller (harus produsen langsung). Sistem kurasi dilakukan secara periodikal oleh pengelola Pasar Moncer untuk menjaga kekhasan produk Pasar Moncer yang aman, enak, dan sehat. Kegiatan pameran terakhir Pasar Moncer, terdapat 110 UMKM yang mendaftar namun hanya sekitar 33 UMKM yang bisa memenuhi kriteria kurasi dari pengelola. Anggota UMKM yang memenuhi kurasi menandatangi pakta integritas untuk menjaga profesionalisme mereka pada kegiatan Pasar Moncer. Ke depan, 
Pasar Moncer akan membuat sistem rolling untuk anggota UMKM yang mengikuti pameran untuk menjaga konsumen agar tidak bosan menghadiri kegiatan Pasar Moncer . Segmen konsumen Pasar Moncer terutama adalah konsumen yang peduli pada kesehatan mereka, kosumen yang memiliki life style sehat, dan konsumen yang membutuhkan produk khsusus seperti anak autis yang butuh gluten free. Harapannya, dengan adanya Pasar Moncer ini, konsumen dapat bertemu dengan produsen langsung yang memiliki produk kualitas baik untuk kesehatan mereka dan lebih dalamnya lagi, konsumen dapat diajak juga untuk peduli pada lingkungan mereka bersama dengan komunitas di dalam Pasar Moncer ini.

Dalam kaitannya dengan penciptaan nilai, Pasar Moncer berkomitmen untuk dapat memberikan manfaat sosial yang berkelanjutan. Hal ini dilakukannya melalui hubungannya dengan anggota komunitas sebagai mitra Pasar Moncer yaitu dengan melakukan proses mentoring terus menerus pada UMKM agar mampu naik kelas ke level yang lebih baik. Proses mentoring ini juga diwadahi tidak hanya dari pengeloala Pasar Moncer saja namun juga dari Disperindag, sesama anggota komunitas, bahkan juga konsumen yang memberikan masukan pada produk mereka. Aktivitas kunci lain yaitu pelatihan untuk anggota komunitas terkait pengembangan usaha juga peran mereka dalam menjaga lingkungan mereka melalui adanya melek lingkungan kesehatan lewat produk mereka. Kelemahan UMKM umumnya adalah belum adanya SOP sehingga produk mereka kadang mengalami perubahan kualitas. hal inilah yang dilatihkan pengelola Pasar Moncer kepada anggotanya.

Dalam kaitannya dengan penangkapan nilai, Pasar Moncer ini merupakan komunitas non profit yang menjalankan kegiatannya untuk keberlanjutan ekonomi. Hanya saja untuk melaksanakan kegiatan ini diperlukan beberapa perngeluaran operasional, untuk itu, pembiayaan anggota yang berupa iuran diambil dari persentase share profit hasil penjualan yang nantinya dipakai untuk memberikan insentif pada pekerja lepas pameran, sewa tempat dan operasional lainnya. Laporan keuangan masih bersifat sederhana namun dipublikasikan kapda seluruh anggota sehingga semua terjalin dengan transparan. Konsistensi Pasar Moncer dalam membesarkan anggota komunitas dan peduli pada lingkungan sosial untuk keberlajutan usaha inilah yang menjadi value utamanya. Lama kelamaan, value Pasar Moncer tersebar luas diantara konsumen tanpa mereka sadari. 
Dilihat dari kekuatan internalnya, komunitas Pasar Moncer memiliki keunggulan di anggota komunitas yang sudah melalui proses kurasi terlebih dahulu dan berpakta integritas. Selain itu, kekerabatan dan kekeluargaan adalah ciri khas sesama anggota Pasar Moncer. Prinsipnya, komunitas Pasar Moncer ini hadir untuk menjaga motivasi anggota UMKM menjalankan bisnis secara berkelanjutan untuk menjaga komitmen UMKM dalam mengembangkan produknya yang sejalan dengan aspek tripple bottom line karena memang tidak mudah. Tantangan terbesarnya di sumber daya manusia UMKM itu sendiri. Tantangan lain ada pada edukasi konsumen bahwa produk yang mereka konsumsi itu sudah sehat dan aman untuk dikonsumsi atau belum juga hasil produk itu dikelola dengan misi keberlanjutan atau tidak. Masih banyak konsumen yang tidak peduli akan hal ini. Besar harapan Pasar Moncer untuk membawanya ke ranah Nasional bahkan Internasional.

\section{Praktek Model Bisnis Berkelanjutan pada Komunitas UMKM Pasar Mustokoweni}

Pasar mustokoweni adalah komunitas UMKM yang menjual makanan produsen lokal Jogja dengan bahan alami, sehat dan organik. Produk yang dipamerkan dalam Pasar Mustokoweni ini banyak juga yang kekinian namun sehat yaitu mulai dari appetizer, main course, dan dessert dibuat tanpa bahan pengawet sedikitpun. Pasar Mustokoweni ini buka dari pukul 12.00-15.00 WIB setiap minggu kedua dan keempat dan berlokasi di Mustokoweni the Heritage Hotel tepatnya di Jl. Mangkubumi No.72 Jetis. Pasar Mustokoweni ingin menyebarkan gerakan dan suasana lingkungan yang positif dari berbagai aspek secara holistik. Salah satu hal yang menarik adalah konsumen diajak untuk membawa tempat makan dan minum sendiri untuk mengurangi banyaknya sampah plastik.

Pasar Mustokoweni itu sendiri membantu anggota komunitas untuk melakukan kegiatan bisnis yang berkelanjutan sehingga tidak hanya berpikir profit saja namun juga mengusung nilai kepedulian sosial dan lingkungan. Hal ini dilakukan dengan beberapa kegiatan berikut ini:

1. Konsep sehat yang disepakati bersama. Konsep sehat itu sendiri kadang berbeda untuk setiap orang. Oleh karena itu, komunitas membanti anggota untuk mengarahkan produknya menjadi produk yang sehat dan aman untuk di 
konsumsi pelanggan dengan kriteria tertentu seperti non MSG, non pemanis buatan, non pewarna buatan dan gluten free.

2. Mengajak produsen dan konsumen atau lebih genaral lagi seluruh stakeholder untuk lebih kritis terhadap apa yang mereka konsumsi. Apakah produk tersebut aman dan sehat? Apakah produk tersebut peduli pada lingkungan dan sosial?

3. Mengajak tenan/ anggota komunitas berkembang bersama dengan asas kekeluargaan.

4. Menjadi wadah bertemunya penjual dan pembeli sehingga pembeli bisa menjalin hubungan lebih personal dengan penjual untuk memperdalam mengenai manfaat produk yang ingin dibelinya. Prinsipnya lingkungan yang baik akan memberikan dampak baik pula bagi kehidupan lebih besar.

5. Wadah untuk memperpendek rantai pasok.

6. Peduli lingkungan melalui mengurangi sampah plastik.

Dalam kaitannya dengan proposisi nilai, produk yang dijual dalam Pasar Mustokoweni adalah makanan jadi, hasil kebun, dan beberapa kebutuhan rumah tangga seperti sabun. Produk mengusung nilai keberlanjutan yang setidaknya merupakan tangan pertama produsen, atau produk yang sehat dan aman, atau produk yang peduli pada lingkungan sosialnya. Setelahnya akan dilakukan seleksi makanan organik untuk setiap pendaftar. Segmen konsumen Pasar Mustokoweni ini adalah ibu muda, anak muda dan orang-orang yang memang penasaran dengan produk-produk sehat itu seperti apa. Hubungan personal yang dijalin antara penjual dan konsumen yang datang sangat terlihat dengan banyaknya konsumen loyal yang secara periodik rajin datang memeriahkan kegiatan ini.

Dalam kaitannya dengan penciptaan nilai, aktivitas kunci yang dilakukan komunitas Pasar Mustokoweni ini sejalan dengan yang dilakukan dengan anggota komunitasnya. Anggota komunitas ini sendiri berasal dari relasi kekeluargaan satu sama lain. Tidak ada aturan yang mengikat dan tertulis mengenai keanggotaan komunits Pasar Mustokoweni, semua murni aspek relasi.

Dalam kaitannya dengan penangkapan nilai, komunitas ini bersifat non profit karena memang misinya untuk menyebarkan gerakan peduli lingkungan yang positif dari berbagai aspek secara holistik. Hal ini secara tidak langsung tertangkap misinya 
oleh salah satu stakeholder yaitu pemilik tempat Mustokoweni the Heritage Hotel sehingga tidak membebani biaya sewa tertentu untuk kegiatan Pasar Mustokoweni. Adapun biaya yang muncul hanya berupa iuran anggota per bulan Rp 20.000,- untuk 2x pasar (dalam 1 bulan) digunakan untuk kebersihan lokasi pasar.

Kehadiran Pasar Mustokoweni ini memang peluang besar untuk ditingkatkan skala bisnisnya, namun keterbatasan tenaga pada pengelolaan Pasar Mustokoweni memang menjadi kendala membuat kegiatan ini lebih besar dari sekarang. Prinsipnya, Pasar Mustokoweni ini ingin memberikan dampak lingkungan yang sehat dan bermanfaat bagi orang lain. Pasar Mustokoweni ini juga memberikan ketahanan pada anggota komunitas UMKM dengan mendukung pemangku kepentingan untuk memajukan usaha mereka secara bersama-sama. Secara tidak langsung pula, keberadaan Pasar mustokoweni ini menanamkan kepedulian sosial dan lingkungan juga pada masyarakat.

\section{Tantangan Praktek Model Bisnis Berkelanjutan pada Komunitas UMKM di Yogyakarta}

Penerapan praktik model bisnis berkelanjutan yang tidak mengesampingkan kualitas kehidupan tenaga kerja, komunitas lokal dan masyarakat sekitar ini penting bagi perkembangan ekonomi. Hanya saja dalam pelaksanaannya, membutuhkan komitmen yang tinggi terutama bagi UMKM. Untuk itu, peran komunitas UMKM ini untuk menjaga keberlanjutan komitmen UMKM yang melakukan kegiatan usahanya dengan mempertimbangkan aspek tripple bottom line. Penguatan aspek value proposition, value creation, dan value capture juga dipandang penting bagi UMKM di Indonesia mampu bertahan secara jangka panjang. Pasar Kamisan, Pasar Moncer dan Pasar Mustokoweni ini telah membuktikan perannya dalam menjaga anggota komunitasnya melakukan kegiatan tersebut. Hal ini terlihat dari tabel 3.

Tabel 3. Peran Komunitas terhadap Anggota

\begin{tabular}{lclc}
\hline No & Variabel & \multicolumn{1}{c}{ Indikator } & Nilai Mean \\
\hline $\mathbf{1}$ & Dimensi Ekonomi & Produk inovatif, ketrampilan teknis, & 4,6597 \\
& & jaringan, kemitraan, orientasi & \\
& & kualitas, hubungan pelanggan, & \\
& & pemasaran & \\
\hline $\mathbf{2}$ & Dimensi Lingkungan & $\begin{array}{l}\text { Peduli lingkungan, kebersihan, } \\
\text { kesadaran sampah, ramah }\end{array}$ & \\
& & lingkungan, inisiatif memberi solusi & \\
\hline
\end{tabular}




\begin{tabular}{llll}
\hline & & \multicolumn{3}{l}{ lingkungan, perspektif daur ulang } & \\
\hline 3 & Dimensi Sosial & Peduli sosial, memperkerjakan & 3,7278 \\
& & masyarakat lokal, potensi lokal, & \\
& & sponsor kegiatan sosial & \\
\hline 4 & Peran Komunitas UMKM & $\begin{array}{l}\text { Peran pengembangan usaha, peran } \\
\text { pemasaran, peran kesadaran }\end{array}$ & \\
& & $\begin{array}{l}\text { lingkungan, peran jaringan, peran } \\
\text { kegiatan sosial, peran berkomunitas }\end{array}$ & \\
\hline
\end{tabular}

Tabel 3 mengenai peran komunitas terhadap anggota nampak bahwa hasil rata-rata keseluruhan dimensi menunjukkan bahwa komunitas memiliki peran yang sangat baik bagi kemajuan anggota komunitas. Anggota UMKM merasa terbantu sekali terutama dalam aspek dimensi ekonomi. Mereka dimentoring dan dibimbing untuk naik kelas dari segi usaha mereka, sehingga usaha mereka bisa berkembang lebih baik lagi. Yang masih perlu ditingkatkan adalah dimensi sosial karena memiliki nilai rata-rata terendah.

Untuk mencapai model bisnis berkelanjutan memang tidak mudah, dibutuhkan komitmen yang tinggi karena banyaknya keterbatasan kemampuan dari UMKM itu sendiri. Lingkup UMKM yang sempit dan biaya yang cukup tinggi untuk mengaplikasikan model bisnis berkelanjutan inilah yang menjadi kendala utama UMKM ketika mereka harus berjuang sendiri. Dengan dukungan komunitas, UMKM akan merasa banyak dukungan yang memudahkan teraplikasinya model bisnis berkelanjutan ini. Salah satu solusi yang diusulkan peneliti untuk membangun komunitas UMKM yang mendukung keberlanjutan usaha anggota komunitas mereka melalui gambar 5 berikut ini: 


\begin{tabular}{|c|c|c|}
\hline $\begin{array}{c}\text { Proposisi Nilai } \\
\text { (Value Proposition) }\end{array}$ & $\begin{array}{l}\text { Penciptaan Nilai } \\
\text { (Vaue Creation) }\end{array}$ & $\begin{array}{c}\text { Penangkapan Nilai } \\
\text { (Value Capture) }\end{array}$ \\
\hline $\begin{array}{lr}\text { Pelaksanaan kegiatan } \\
\text { komunitas berdasarkan } \\
\text { aspek tripple bottom } \\
\text { line } & \text { dengan } \\
\text { memaksimalkan } \\
\text { integrasi rran } \\
\text { perusahaan } \\
\text { UMKM) antara } \\
\text { potensi lokal dengan } \\
\text { stakeholder sehingga } \\
\text { akan mendatangkan } \\
\text { keuntungan ran } \\
\text { holistik. }\end{array}$ & $\begin{array}{l}\text { Komunitas UMKM } \\
\text { dalam misi yang } \\
\text { konsisten untuk } \\
\text { mengubah pola pikir/ } \\
\text { mindset anggota supaya } \\
\text { berkomitmen } \\
\text { menjalankan usaha } \\
\text { berkelanjutan terkait , } \\
\text { pengelolaan sumber } \\
\text { dayanya. Menjaga } \\
\text { hubungan kemitraan } \\
\text { mendatangkan } \\
\text { keuntungan sosial dan } \\
\text { lingkungan. }\end{array}$ & $\begin{array}{lr}\text { Peran } & \text { komunitas } \\
\text { UMKM } & \text { ini } \\
\text { berkontribusi } & \text { pada } \\
\text { hubungan } & \text { eksternal } \\
\text { anggota UMKM. Biaya } \\
\text { lingkungan yang rendah } \\
\text { dan bekal lain bagi } \\
\text { anggota UMKM ini akan } \\
\text { menjadi retahanan } \\
\text { tersendiri } \\
\text { perkembangan } \\
\text { UMKM. }\end{array}$ \\
\hline
\end{tabular}

Gambar 5. Solusi Pengembangan Komunitas UMKM

\section{Kesimpulan, Implikasi, Saran dan Keterbatasan}

Kehadiran komunitas UMKM ini penting untuk mendukung setiap UMKM maju bersama menuju ekonomi berkelanjutan. Bahkan hal ini juga menyasar kepada konsumen yang melakukan kegiatan konsumsi produk-produk UMKM. Ketika sebagian besar UMKM melakukan kegiatan yang mengarah pada keberlanjutan, maka pola aktivitas konsumsi dan bisnis dapat pelan-pelan berangsur pada kondisi stabil. Keterbatasan UMKM dalam hal biaya dan komitmen telah berhasil diatasi dengan keberasaan komunitas UMKM ini.

Keberlanjutan komitmen UMKM yang melakukan usaha pertimbangan aspek tripple bottom line ini mampu dicapai dengan peran komunitas UMKM itu sendiri. Lebih lanjut bahwa penguatan aspek value proposition, value creation, dan value capture juga dipandang penting bagi UMKM di Indonesia mampu bertahan secara jangka panjang.

\section{Referensi}

Battistella, C., Cagnina, M., Cicero, L., \& Preghenella, N. (2018). Sustainable business models of SMEs: Challenges in yacht tourism sector. Sustainability, 10(10), 3437. 
Bocken, N. M., Short, S. W., Rana, P., \& Evans, S. (2014). A literature and practice review to develop sustainable business model archetypes. Journal of cleaner production, 65, 42-56.

Bocken, N., Short, S., Rana, P., \& Evans, S. (2014). A value mapping tool for sustainable business modelling. Corporate Governance, 13(5), 482-497.

Boons, F.; Lüdeke-Freund, F. Business models for sustainable innovation: State-ofthe-art and steps towards a research agenda. J. Clean. Prod. 2013, 45, 9-19.

Bommel, K. (2018). Managing tensions in sustainable business models: Exploring instrumental and integrative strategies. Clean. Prod. 45, 20-30.

Bungin, B. (2007). Penelitian Kualitatif. Jakarta: Kencana Prenada Media Group.

Cooper, D. R. dan Schindler, P. S. (2014). Business Research Method (Twelfth Edition). The McGraw-Hill Companies, Inc

Evans, S., Vladimirova, D., Holgado, M., Van Fossen, K., Yang, M., Silva, E. A., \& Barlow, C. Y. (2017). Business model innovation for sustainability: Towards a unified perspective for creation of sustainable business models. Business Strategy and the Environment, 26(5), 597-608.

Høgevold, N. M. (2011). A corporate effort towards a sustainable business model: a case study from the Norwegian furniture industry. European Business Review, 23(4), 392-400.

Morioka, S. N., Evans, S., \& de Carvalho, M. M. (2016). Sustainable business model innovation: Exploring evidences in sustainability reporting. Procedia CIRP, 40, 659-667.

Morioka, S.N.; Bolis, I.; Monteiro de Carvalho, M. (2018) From an ideal dream towards reality analysis: Proposing Sustainable Value Exchange Matrix (SVEM) from systematic literature review on sustainable business models and face validation. J. Clean. Prod., 178, 76-88

Osterwalder, A., Pigneur, Y., 2010. Business Model Generation: A Handbook for Visionaries, Game Changers, and Challengers. John Wiley \& Sons, Hoboken, New Jersey.

Richardson, J. (2008) The business model: An integrative framework for strategy execution. Strat. Chang. 17, 133-144.

Tracy S. J. (2013). Qualitative Research Methods collecting evidence, crafting analysis, communicating impact (versi elektronik). John Wiley \& Sons, Ltd

WWF, 2012. Living Planet Report 2012. Retrieved from the WWW, December 2012: $\quad$ http://awsassets.panda.org/downloads/1_lpr_2012_online_full size single pages final 120516.pdf.

Zimmerer, Thomas W., dan Norman M. Scarborough. (2016). Essentials of Entrepreneurship and Small Business Management. New Jersey: Pearson Education, Inc. 